\title{
Influence of duodenogastric reflux in the gastric mucosa histological changes of rats infected with Helicobacter pylori
}

\section{Influência do refluxo duodenogastrico nas alterações histológicas da mucosa gástrica de ratos infectados com Helicobacter pylori}

José Carlos Ribeiro de Araujo, tCBC-MA; Jorge José de Carvalho²; Humberto Oliveira Serra, TCBC-MA¹.

\begin{abstract}
A B S T R A C T
Objective: to evaluate the influence of Duodenal reflux in histological changes of the gastric mucosa of rats infected with Helicobacter pylori submitted to pyloroplasty. Methods: after two weeks of acclimation, we infected 30 male Wistar rats with Helicobacter pylori. We randomly divided them into three groups: one submitted to pyloroplasty, another to partial gastrectomy and the third, only infected, was not operated. After six months of surgery, euthanasia was carried out. Gastric fragments were studied by light microscopy to count the number of H. pylori, and to observe the histological changes (gastritis, metaplasia, dysplasia and neoplasia). We confirmed these changes by immunohistochemistry using the molecular markers PCNA and TGF-beta. Results: the animals submitted to pyloroplasty had higher percentage of colonization by $\mathrm{H}$. pylori (median=58.5; gastrectomy=16.5; control=14.5). There was a positive correlation between the amount of $\mathrm{H}$. pylori and the occurrence of chronic gastritis present in the antral fragments. Neoplasia occurred in $40 \%$ of rats from the group submitted to pyloroplasty. The staining with PCNA and TGF-B confirmed the histopathological changes visualized by optical microscopy. Conclusions: the antral region was the one with the highest concentration of $H$. pylori, regardless of the group. There was a positive correlation between the appearance of benign disorders (chronic gastritis, metaplasia, dysplasia) and cancer in mice infected with H. pylori submitted to pyloroplasty.
\end{abstract}

Keywords: Stomach Neoplasms. Helicobacter pylori. Duodenogastric Reflux. Rats, Wistar.

\section{INTRODUCTION}

G astric cancer, a public health problem worldwide, continues to be the most common malignancy of the digestive tract in humans, especially among the elderly ${ }^{1-2}$. In Brazil, it is the second most prevalent cancer in men and the fifth in women. Its incidence has decreased, but its prognosis little changed in recent years due to diagnosis made at an advanced stage of disease progression ${ }^{3-5}$.

Several factors are involved in the genesis of gastric cancer, such as environmental and dietary factors, with emphasis on foods rich in nitrates and nitrites, $\mathrm{H}$. pylori infection (a gram-negative spiral bacterium that is often associated with chronic gastritis, intestinal metaplasia and dysplasia) and duodenogastric reflux ${ }^{6-8}$.

Although $H$. pylori is the main risk factor for gastric cancer and is present in over $50 \%$ of the world population, it is estimated that only $3 \%$ develop gastric cancer, leading to the belief that no etiological factor acts in isolation in gastric carcinogenesis ${ }^{7-9}$.

Duodenogastric reflux is a common physiological event in the postprandial period or prolonged fasting. However, depending on the rhythm, volume and duration of gastric mucosal exposure, it can be highly pathogenic, by changing the physicochemical characteristics of the protective mucus layer, increase gastric $\mathrm{pH}$, thus favoring bacterial and $n$-compounds proliferation ${ }^{10-12}$.

The objective of this study was to evaluate the influence of Duodenal reflux on the gastric mucosa of rats infected with $H$. pylori and submitted to partial gastrectomy or pyloroplasty.

\section{METHODS}

\section{Animals and Experimental Protocol}

We used 30 male, albino Wistar rats, aged 24 weeks and an average weight of $250 \mathrm{~g}$. We kept them un-

1 - Department of Medicine II, Federal University of Maranhão (UFMA), Sao Luis, MA, Brazil. 2 - University of the State of Rio de Janeiro (UERJ), Rio de Janeiro, RJ, Brazil. 
der normal conditions of pressure, temperature and light and with free access to food and water. After two weeks of acclimation, we infected them with Helicobacter pylori.

Before receiving the bacterial load, they fasted for 24 hours. Thereafter, they first received $1 \mathrm{~mL}$ of $\mathrm{NaHCO}_{3}$ by gavage with a metal orogastric catheter, according to the method described by Konturek ${ }^{13}$. Shortly thereafter, also by orogastric gavage, we inoculated $1 \mathrm{ml}$ of $H$. pylori ATCC 43504 (9x108) in Mueller-Hinton suspension. Each animal received three equal doses with an interval of two days between each application. The rodents had free access to food and water after the first application.

Fifteen days after the last inoculation, we randomly divided the animals into three groups $(n=10)$ : Group I- Infection (control); Group G- Gastrectomy (undergoing partial gastrectomy) and Group P- Pyloroplasty (submitted to pyloroplasty). All animals survived and were sacrificed after 24 weeks.

\section{Microorganism}

The stock of $H$. pylori were maintained in Muller Hinton broth (Himedia, Mumbai, India) at a temperature of $-20^{\circ} \mathrm{C}$ in $20 \%$ glycerol. The inoculated bacteria were prepared in Agar (Becton, Dikinson \& Company) plates (90x15mm) supplemented with $5 \%$ sheep blood or in $\mathrm{BHI}$ and maintained in a jar with a microaerophilic and $\mathrm{O}_{2}$ and $\mathrm{CO}_{2}$ gas generator "sachet" (Probac do Brazil) for three to five days at $37^{\circ} \mathrm{C}$. The morphological identification and bacterial activity were based on microerophilic requirement for bacterial growth and on the Gram stain.

\section{Surgery}

Within the 24 hours before the surgical procedure the animals of $G$ and $P$ groups had access only to water. The anesthetic technique used was the inhalation of sulfuric ether in closed tanks for initial sedation and intramuscular ketamine in the back of the thigh, at a dose of $50 \mathrm{mg} / \mathrm{kg}$. All animals were operated under aseptic conditions.

All 20 animals underwent laparotomy from the xiphoid to the abdominal middle third. Two Halsted-type clamps were placed, one on each side of the wall to act, by their own weight, as retractors. The liver was retracted and the stomach was exteriorized through the incision by stitches traction, allowing the development of an extra-cavity technique. The abdominal wall was closed with 3-0 prolene continuous running suture reaching all planes. Rats were offered ad libitum feeding postoperatively.

\section{Partial gastrectomy}

We performed the resection of $2 / 3$ of the antrum and half of the gastric body, preserving the pylorus and vagus nerves. The gastric reconstruction was performed by simple running suture with 5-0 Prolene with a $1.5 \mathrm{~cm}$ cylindrical needle. All the animals of group $\mathrm{G}$ were operated on the same day.

\section{Pyloroplasty}

We made a $2 \mathrm{~cm}$, whole-plane longitudinal incision $(1 \mathrm{~cm}$ in the stomach and $1 \mathrm{~cm}$ in the duodenum). We closed the pylorus in the transverse direction with a simple running suture of 5-0 Prolene with a $1.5 \mathrm{~cm}$ cylindrical needle in a Heinecke-Mikulicz fashion.

We closed the abdominal wall with a wholeplane, 3-0 Prolene running suture. All the animals of group $\mathrm{P}$ were operated on the same day.

\section{Euthanasia and Technical Preparation of Specimens}

Twenty-four hours prior to euthanasia, animals were deprived of food, and then deeply anesthetized (sodium pentobarbital, $150 \mathrm{mg} / \mathrm{kg}$ ). The whole stomach was removed and sectioned longitudinally into two halves (anterior and posterior), which were quickly placed in a solution of $1.27 \mathrm{~mol} / /$ of formaldehyde $(0.1 \mathrm{M}$ phosphate buffer, pH 7.2) for 48 hours. The material was included with the cut side down (both halves, each containing antrum, body and fundus).

We treated the fragments in a histotechnical apparatus (tissue processor - Micom GMBH), embedded them in paraffin by means of self-entraining instrument (Microm AP280), and cut them in five-micrometer thick slices with a ZEISS-HYRAXMIS microtome. We made two histological sections from the parts stained with hematoxylin-eosin and modified Giemsa. We evaluated the 
Table 1. Amount of H. pylori in different gastric segments according to the groups.

\begin{tabular}{lcccc}
\hline & \multicolumn{3}{c}{ Median amount $h$. pylori } & \\
\cline { 2 - 4 } \multicolumn{1}{c}{ Location } & Pyloroplasty & Gastrectomy & Infection & Kruskal-Wallis (p value) \\
\hline Antrum & 58.5 & 16.5 & 14.5 & 0.310 \\
Body & 4.0 & 1.5 & 1.5 & 0.560 \\
Fundus & 4.0 & 7.0 & 2.0 & 0.161 \\
\hline
\end{tabular}

histological slides under an optical microscope (NIKON ECLAPSE 200).

We analyzed the sections by immunohistochemistry with marking for TGF-B and PCNA. For antigen retrieval, we used citrate buffer, $\mathrm{pH} 6.0$ at $60^{\circ} \mathrm{C}$ and then blocked with ammonium chloride, $2 \%$ glycine and phosphate buffer, pH 7.4 (PBS). The sections were incubated with a specific primary rat antibody, both at a concentration of 1:100 (Santa Cruz Biotechnology, Santa Cruz, CA, USA) overnight at $4^{\circ} \mathrm{C}$. Then, the samples were incubated for 1 hour at room temperature with a biotinylated secondary antibody (K0679, Universal DakoCitomation LSAB + Peroxidase Kit; DakoCitomation Glostrup, Denmark). We used a horse anti-rat secondary antibody detectable by reaction of the streptavidin-biotin-enzyme complex. Positive immunostaining was identified after incubation with diaminobenzidine 3,3'-tetrachloride (K3466, DAB; DakoCitomation) and contrasted with Mayer hematoxylin.

On histological analysis, we studied 100 glands of each gastric segment (antrum, body and fundus) for detection of $\mathrm{H}$. pylori and inflammation, metaplasia, dysplasia and neoplasia in optical microscopy in 40x, 100x and 400x magnifications. We classified results as: normal, gastritis, metaplasia, dysplasia and neoplasia.

We considered the study of the gastric mucosa: (a) Normal- absence of neutrophils and the presence of up to ten lymphocytes and plasma cells in the lamina propria per 400X microscopic field; (b) Chronic gastritispresence of predominantly mononuclear cells (lymphocytes and plasma cells); we measured chronicity by the density of the lymphocyte, plasma cells and polymorphonuclear cells infiltration in the lamina propria Gastritis and its activity followed the modified Sydney classification ${ }^{14}$; (c) Metaplasia- presence of intestinal cells in the stomach mucosa; (d) Dysplasia- distortion of intraepithelial cytoar- chitecture (increase of the cell population, loss of polarity, decreased mucus, proliferation of cells and glands, change in glands' shape); (e) Neoplasia- same features of dysplasia plus extraepithelial invasion.

As for gastric layers, we considered the involvement restricted to the mucosa of the antrum, body and fundus.

\section{Statistical analysis}

We used the Shapiro-Wilk test to assess the normality of quantitative variables. We calculated the differences between the medians of quantitative variables without normal distribution using the Kruskal-Wallis test. To evaluate the differences between the proportions of categorical variables, we used the Fisher's exact test. In all analyzes we considered as significant the level of $p=0.05$.

\section{Ethics Committee}

The experimental protocol was approved by the Ethics in Research Committee of the State University of Rio de Janeiro (UERJ) for Care and Use of Laboratory Animals (CEA / 001/2010).

\section{RESULTS}

The median amount of $H$. pylori found in the 100 glands of each gastric segment, when compared between groups, was higher in the antrum of the animals submitted to pyloroplasty (median $=58.5$ ), although this difference with respect to the others (gastrectomy=16.5 and control=14.5) was not significant ( $p>0.05$ - Kruskal-Wallis test), as shown in table 1.

When comparing the population of $\mathrm{H}$. pylori according to the gastric segment studied, regardless of the group, we found that the antrum was also the site with the highest amount of bacteria (Table 2). 
Table 2. Amount of H. pylori according to the location in the stomach.

\begin{tabular}{lccc}
\hline \multicolumn{1}{c}{ Location } & $\mathrm{n}$ & Median & Interquartile range \\
\hline Antrum & 30 & 21 & 66 \\
Body & 30 & 2 & 5 \\
Fundus & 30 & 3.5 & 8 \\
\hline
\end{tabular}

There was a positive correlation between the amount of $H$. pylori present in the antrum of the fragments and the occurrence of chronic gastritis, metaplasia, dysplasia and neoplasia, especially in animals submitted to pyloroplasty. We observed no correlation between these variables and the ones studied in the body and fundus fragments (Tables 3 and 4).

Table 5 shows that there were significant differences in the proportions of histological changes in the antrum mucosa of the groups studied observed by optical microscopy. There was $40 \%$ of cancer in the group submitted to pyloroplasty, with no occurrence of this change in $G$ and I groups ( $p=0.023$ - Fisher's exact test). We observed dysplasia in $50 \%$ of rats with pyloroplasty and $10 \%$ in the group of gastrectomy. The infected group did not show this change $(p=0.027$ - Fisher's exact test).

We confirmed the histological changes in the gastric mucosa by immunohistochemistry with marking for TGF- $\beta$ and PCNA, as shown in figures 1 and 2 .

\section{DISCUSSION}

Gastric carcinoma is one of the rarest spontaneous cancers in animals. The first model developing adenocarcinoma in rats used the carcinogen $\mathrm{N}, \mathrm{N}-2,7$-fluorenyl acetamide enebi $(2,7-F A A)^{15}$. H. pylori infection in- duces chronic inflammation of the gastric mucosa, which leads to destruction of the protective barrier that coats the stomach mucosa, allowing the gastric acid to harm the mucosa, leading to the development of various types of neoplasms, though through unknown development mechanisms ${ }^{16}$.

In this study, there was predominance of benign proliferative lesions, with four malignant neoplasms located in the gastric antrum, at the pyloroplasty suture line. This location is the most common in experimental work that perform partial gastrectomy with Billroth II reconstruction or gastroenterostomy without gastric resection $^{17-19}$.

The sum of factors, such as the infectious process, inflammation and pyloroplasty, could provide a stimulus to cell proliferation. The increase in cell proliferation is one of the prerequisites for carcinogenesis. In the present study, the cuts treated with the immunoperoxidase technique for evidencing PCNA, which identifies cell proliferation, showed the majority of immunostaining at the region of the pyloroplasty suture line, in the gastric antrum. The works of Rodrigues et al. ${ }^{20}$ and Taylor et al. ${ }^{21}$ corroborate these assertions.

There is belief that the region of the anastomosis may have features that facilitate the development of malignancies, such as chronic inflammation, the presence of foreign body (suture) and continuous contact with

Table 3. Correlation between the amount of H. pylori and gastric mucosal changes considering all groups.

\begin{tabular}{lcccccc}
\hline & \multicolumn{7}{c}{ Location } \\
\cline { 2 - 7 } \multicolumn{1}{c}{ Variable } & \multicolumn{2}{c}{ Antrum } & \multicolumn{3}{c}{ Body } & \multicolumn{2}{c}{ Fundus } \\
\cline { 2 - 7 } & \multicolumn{1}{c}{$\mathrm{r}$} & $\mathrm{p}$ & $\mathrm{r}$ & $\mathrm{p}$ & $\mathrm{r}$ & $\mathrm{p}$ \\
\hline Chronic gastritis & 0.5741 & 0.0009 & 0.1689 & 0.372 & 0.4065 & 0.258 \\
Metaplasia & 0.6886 & $<0.0001$ & - & - & -0.0653 & 0.7316 \\
Dysplasia & 0.6344 & 0.0002 & - & - & - & - \\
Neoplasia & 0.5283 & 0.0027 & - & - & - & - \\
\hline
\end{tabular}

Test: Spearman's rank Correlation 
Table 4. Correlation between the amount of H. pylori and the gastric mucosal changes of the rats submitted to pyloroplasty.

\begin{tabular}{lccccccc}
\hline & \multicolumn{7}{c}{ Location } \\
\cline { 2 - 7 } \multicolumn{1}{c}{ Variable } & \multicolumn{2}{c}{ Antrum } & \multicolumn{1}{c}{ Body } & \multicolumn{2}{c}{ Fundus } \\
\cline { 2 - 7 } & $\mathrm{r}$ & $\mathrm{p}$ & $\mathrm{r}$ & $\mathrm{P}$ & $\mathrm{r}$ & $\mathrm{p}$ \\
\hline Chronic gastritis & 0.5660 & 0.0881 & 0.3858 & 0.2709 & 0.6986 & 0.0246 \\
Metaplasia & 0.8730 & 0.0010 & - & - & - & - \\
Dysplasia & 0.8032 & 0.0051 & - & - & - & - \\
Neoplasia & 0.8554 & 0.0016 & - & - & - & - \\
\hline
\end{tabular}

duodenogastric content. The sections immunomarked with anti-TGF-B antibody showed higher positivity in the antrum, where the suture line is located. Whal et al..22 showed that TGF-B is a potent chemotactic for leukocytes, including neutrophils, monocytes and mast cells, and is involved in the formation of the inflammatory infiltrate, especially in chronic inflammatory lesions. Our findings concerning higher TGF- $\beta$ immunostaining in the antrum showed the presence of inflammatory infiltrate, which facilitates the development of cancer.

To date no isolated factor may be implicated in gastric carcinogenesis. The combination of factors, on the other hand, has proved significant in the development of these tumors, such as duodenogastric reflux and $\mathrm{H}$. pylori infection. Both are known etiologic factors of chronic gastritis, thus capable of leading to the sequence of events that begins with atrophic gastritis and progress to intestinal metaplasia, dysplasia and neoplasia. The exacerbated proliferative state in the suture lines, as demonstrated in our work, or in lesions without surgery, become easy targets for the action of endogenously formed carcinogens, such as $\mathrm{N}$-nitrous compounds that, in hypochondriac stomachs colonized by reducing bacteria, turn nitrate into nitrite ${ }^{23}$.
Recent evidence demonstrates that $H$. pylori strains possess genotypic diversity, whose products trigger the inflammatory process through cytokines, which can lead to varying degrees of host inflammatory response, resulting in different pathological alterations. However, how the bacterium contributes to this process is yet to be determined ${ }^{24}$.

Our study showed a higher concentration of H. pylori in the antro-pyloric region, the main place of development of intestinal-type gastric cancer. There was a positive correlation between the amount of $\mathrm{H}$. pylori and the occurrence of metaplasia $(r=0.6886, p=0.0001)$, dysplasia $(r=0.6344, p=0.0002)$ and neoplasia $(r=0.5283$, $p=0.0027$ ) present in the antrum fragments. We found no correlation between these and the variables studied in the body and fundus fragments.

The alkali reflux promoted by pyloroplasty elevates the gastric $\mathrm{pH}$ and promotes bacterial proliferation, which contributes to atrophy of the gastric mucosa and, especially through contact with bile salts and their detergent properties, allowing the penetration of carcinogens through the mucosal barrier, facilitating their action in the mucosal proliferative compartment ${ }^{25}$.

Table 5. Changes in the mucosa of the antrum in the different groups.

\begin{tabular}{|c|c|c|c|c|c|c|c|}
\hline \multirow[b]{3}{*}{ Presence in the Antrum } & \multicolumn{6}{|c|}{ Group } & \multirow{3}{*}{$\frac{\text { Fisher exact test }}{\mathrm{p} \text { value }}$} \\
\hline & \multicolumn{2}{|c|}{ Pyloroplasty (P) } & \multicolumn{2}{|c|}{ Gastrectomy (G) } & \multicolumn{2}{|c|}{ Infected (I) } & \\
\hline & $n$ & $\%$ & $n$ & $\%$ & $\mathrm{~N}$ & $\%$ & \\
\hline Chronic gastritis & 10 & 100 & 10 & 100 & 10 & 100 & - \\
\hline Metaplasia & 5 & 50 & 3 & 30 & 0 & 0 & 0.53 \\
\hline Dysplasia & 5 & 50 & 1 & 10 & 0 & 0 & 0.027 \\
\hline Neoplasia & 4 & 40 & 0 & 0 & 0 & 0 & 0.023 \\
\hline
\end{tabular}




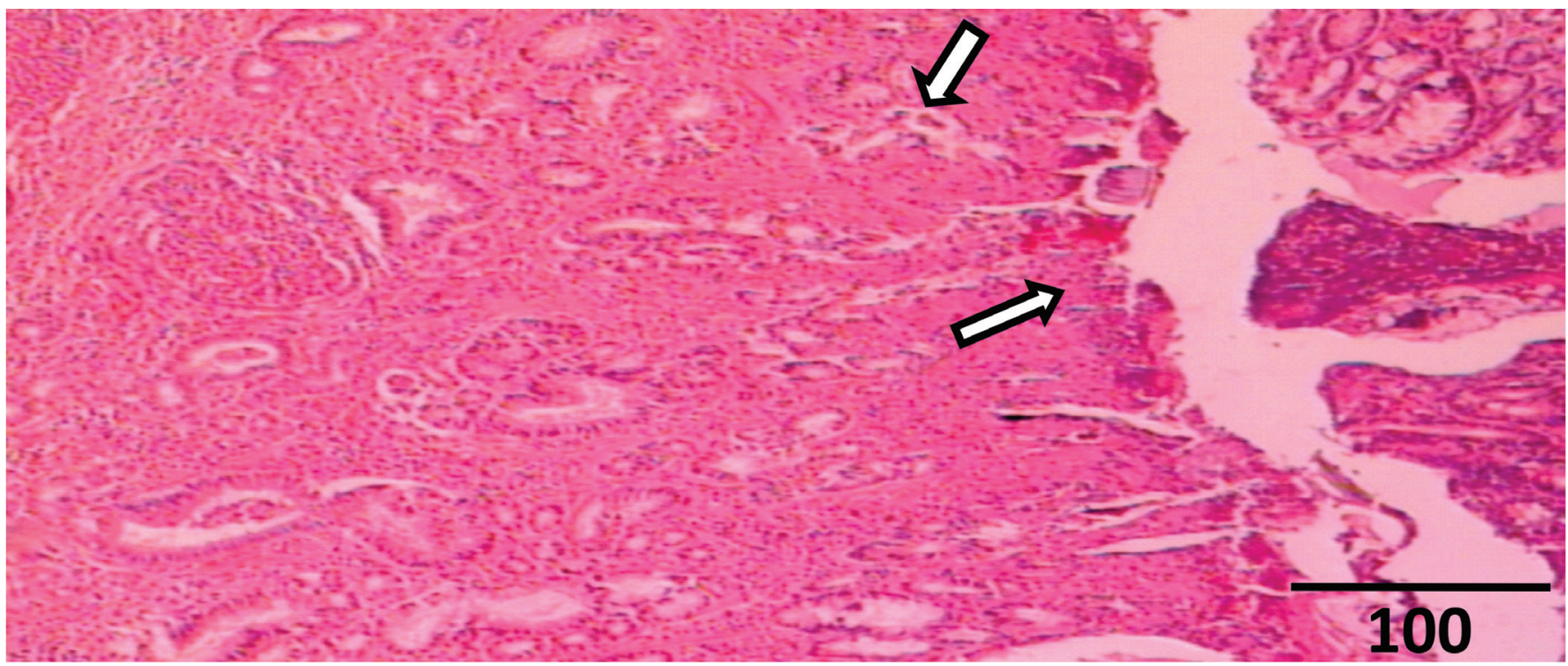

Figure 1. Presence of neoplasia, with irregularity of the gastric glands, which are not parallel, have different sizes, and forked presentation.

Our study showed a greater amount of $H$. pylo$r i$ in the antrum of the animals submitted to pyloroplasty, although this difference with the other groups was not significant. When comparing the population of $\mathrm{H}$. pylori according to the studied gastric segment, regardless of the group, the antrum was also the place where we found the highest amount of bacteria.

This suggests that there may be some relationship between the duodenogastric reflux and the malignant transformation of the epithelium of the distal third of the stomach, where the contact of the reflowed material with the mucosa is more intense, which would justify the high frequency of adenocarcinomas in this region in mice infected with $H$. pylori ${ }^{20}$.

Kamata ${ }^{26}$ reported $20.8 \%$ of gastric adenocarcinoma in a group of rats undergoing gastrectomy with Billroth II reconstitution. He found no cases of carcinoma in rats undergoing Billroth I gastrectomy, even with the removal of the pylorus (reflux-inducing surgery), indicating that the importance is in the larger amount of reflowable content. In this study, we found $40 \%$ of adenocarcinoma in rats submitted to pyloroplasty in a 24-week infection.

Kobori et al. ${ }^{27}$ studied the relationships of reflux through the pylorus in rats and the development of malignant lesions in a 50-week follow-up and observed a $41 \%$ incidence of adenocarcinoma in the mucosa of the antrum. Kaminishi et al.28 in a similar study performing surgery for induction of duodenogastric reflux through the pylorus, with the 30-week observation period, did not find malignant lesions. However, these conclusions are subject to criticism, since most of duodenogastric reflux detection methods result from inaccurate measurements due to the intermittent nature of reflux or to intrinsic methodology flaws ${ }^{29}$.

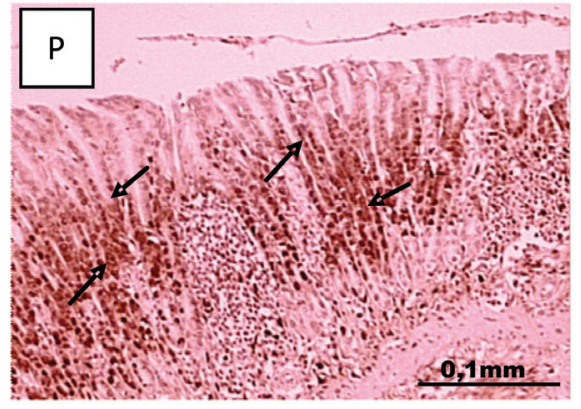

Pyloroplasty Group

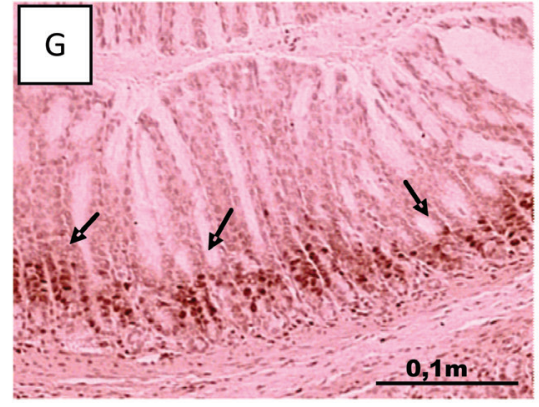

Gastrectomy Group

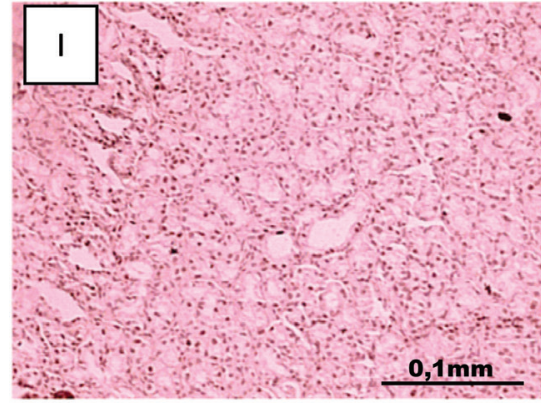

Infected Group

Figure 2. Histological section of the antrum mucosal expression of PCNA in the groups studied. 
Concluding, the antral region was the one with the highest concentration of $H$. pylori, regardless of group. There was a positive correlation between the ap- pearance of benign disorders (chronic gastritis, metaplasia, dysplasia) and cancer in rats infected with $H$. pylori submitted to pyloroplasty.

\title{
R E S U M O
}

\begin{abstract}
Objetivo: avaliar a influência do refluxo duodenogástrico nas alterações histológicas da mucosa gástrica de ratos, infectados por Helicobacter pylori, submetidos à piloroplastia. Método: após duas semanas de aclimatação, 30 ratos machos da raça Wistar, foram infectados com o microorganismo patogênico $H$. pylori. De forma aleatória, foram divididos em três grupos: um submetido à piloroplastia, outro à gastrectomia parcial e o terceiro, apenas infectados, não foi operado. Após seis meses de operados, procedeu-se a eutanásia. Os fragmentos gástricos foram estudados por microscopia óptica, para a contagem da quantidade de $H$. pylori, e para a observação das alterações histológicas (gastrite, metaplasia, displasia e neoplasia). A confirmação dessas alterações foi feita por imuno-histoquímica, utilizando os marcadores moleculares PCNA e TGFbeta. Resultados: os animais submetidos à piloroplastia tiveram maior percentual de colonização por $H$. pylori (mediana=58,5; gastrectomia=16,5; controle=14,5). Houve correlação positiva entre quantidade de $H$. pylori e ocorrência de gastrite crônica presente nos fragmentos do antro. Ocorreu $40 \%$ de neoplasia no grupo submetido à piloroplastia. A marcação de PCNA e TGF-beta confirmou as alterações histopatológicas visibilizadas à microscopia óptica. Conclusões: a região do antro foi a que apresentou a maior concentração de H. pylori, independente do grupo. Houve correlação positiva entre e o aparecimento de alterações benignas (gastrite crônica, metaplasia, displasia), e de neoplasia nos ratos infectados com H. pylori submetidos à piloroplastia.
\end{abstract}

Descritores: Neoplasias Gástricas. Helicobacter pylori. Refluxo Duodenogástrico. Ratos Wistar.

\section{REFERENCES}

1. Parkin DM, Bray F, Ferlay J, Pisani P. Global cancer statistics, 2002. CA Cancer J Clin. 2005;55(2):74-108.

2. Hu B, El Hajj N, Sittler S, Lammert N, Barnes R, Meloni-Ehrig A. Gastric cancer: classification, histology and application of molecular pathology. J Gastrointest Oncol. 2012;3(3):251-61.

3. Liu X, Cai H, Wang Y. Prognostic significance of tumour markers in Chinese patients with gastric cancer. ANZ J Surg. 2012;84(6):448-53.

4. Katsube T, Murayama M, Isohata N, Asaka S, Yamaguchi K, Kuhara K, et al. The efficacy of endoscopic submucosal dissection compared with modified endoscopic aspiration mucosectomy by assessing the shortterm therapeutic results for differentiated mucosal gastric cancer. Anticancer Res. 2009;29(10):4271-4.

5. Naka T, Iwahashi M, Nakamori M, Nakamura M, Ojima $T$, lida $T$, et al. The evaluation of surgical treatment for gastric cancer patients with noncurative resection. Langenbecks Arch Surg. 2012;397(6):959-66.

6. Kono S, Hirohata T. Nutrition and stomach cancer. Cancer Causes Control. 1996;7(1):41-55.

7. Peek RM Jr, Moss SF, Tham KT, Pérez-Pérez Gl, Wang S, Miller GG, et al. Helicobacter pylori cagA+ strains and dissociation of gastric epithelial cell proliferation from apoptosis. J Natl Cancer Inst. 1997;89(12):863-8.

8. Araújo MG, Hilário F, Nogueira LG, Vilegas W, San- tos LC, Bauab TM. Chemical constituents of the methanolic extract of leaves of Leiothrix spiralis Ruhland and their antimicrobial activity. Molecules. 2011;16(12):10479-90.

9. Epplein $M$, Zheng $W$, Xiang YB, Peek RM Jr, Li H, Correa $\mathrm{P}$, et al. Prospective study of Helicobacter pylori biomarkers for gastric cancer risk among Chinese men. Cancer Epidemiol Biomarkers Prev. 2012;21(12):2185-92.

10. Ritchie WP Jr. Alkaline reflux gastritis. An objective assessment of its diagnosis and the tratamento. Ann Surg. 1980;192(3):288-98.

11. Langhans P, Heger RA, Hohenstein J, Schlake W, Bünte $H$. Operation-sequel carcinoma of the stomach. Experimental studies of surgical techniques with or without resection. World J Surg. 1981;5(4):595605.

12. Kawiorski W, Herman RM, Legutko J. [Current diagnosis of gastroduodenal reflux and biliary gastritis]. Przegl Lek. 2001;58(2):90-4. Polish.

13. Konturek PC, Brzozowski T, Konturek SJ, Stachura J, Karczewska E, Pajdo R, et al. Mouse model of Helicobacter pylori infection: studies of gastric function and ulcer healing. Aliment Pharmacol Ther. 1999;13(3):333-46.

14. Dixon MF, Genta RM, Yardley JH, Correa P. Classification and grading of gastritis. The updated Sydney System. International Workshop on the Histo- 
pathology of Gastritis, Houston 1994. Am J Surg Pathol.1996;20(10):1161-81.

15. Morris HP, Wagner BP, Ray FE, Snell KC, Stewart HL Comparative study of cancer and other lesions of rats fed N.N'-2,7-fluorenylene-bisacetamide or N-2-fluorenylacetamide. Nat Cancer Inst Monogr. 1961;5:1-53.

16. Nema $\mathrm{H}$, Kato M. Comparative study of therapeutic effects of PPI and H2RA on ulcers during continuous aspirin therapy. World J Gastroenterol. 2010;16(42):5342-6.

17. Mason RC. Duodenogastric reflux in rat gastric carcinoma. Br J Surg 1986;73(10):801-3.

18. Chan DC, Fan YM, Lin CK, Chen CJ, Chen CY, Chao YC. Roux-en-Y reconstruction after distal gastrectomy to reduce enterogastric reflux and Helicobacter pylori infection. J Gastrointest Surg. 2007;11(12): 1732-40.

19. Kaminski EMF, Kruel CDP. Modelo de carcinogênese gástrica utilizando piloroplastia de Finney: estudo experimental em ratos. $A B C D$, arq bras cir dig. 2011;24(4):296-304.

20. Rodrigues PA, Naresse LE, Leite CVS, Rodrigues MAM, Kobayashi. O refluxo duodeno-gástrico (RDG), através do piloro, induz lesões proliferativas gástricas em ratos? Acta Cir Bras. 2002;17(3):160-7.

21. Taylor PR, Mason RC, Filipe MI, Vaja S, Hanley DC, Murphy GM, et al. Gastric carcinogenesis in the rat induced by duodenogastric reflux without carcinogens: morphology, mucin histochemistry, polyamine metabolism, and labelling index. Gut. 1991;32(12):1447-54.

22. Wahl SM, Costa GL, Mizel DE, Allen JB, Skaleric U, Mangan DF. Role of transforming growth factor beta in the pathophysiology of chronic inflammation. J Periodontol. 1993;64(5 Suppl):450-5.

23. Thomazini CM, Pinheiro NA, Pardini MI, Naresse LE, Rodrigues MAM. Infecção por Helicobacter pylori e câncer gástrico: frequência de cepas patogênicas cagA e vacA em pacientes com câncer gástrico. J Bras Patol Med Lab. 2006;42(1):25-30.

24. Ladeira MSP, Salvadori DMF, Rodrigues MAM. Biopatologia do Helicobacter pylori. J Bras Patol Med Lab. 2003;39(4):335-42.

25. Miwa K, Hasegawa $H$, Fujimura $T$, Matsumoto $H$, Miyata R, Kosaka T, et al. Duodenal reflux through the pylorus induces gastric adenocarcinoma in the rat. Carcinogenesis. 1992;13(12):2313-6.

26. Kamata T. [Experimental studies on the development of residual stomach cancer--comparison of Billroth I and Billroth II]. Nihon Geka Gakkai Zasshi. 1993;94(2):104-13. Japanese.

27. Kobori O, Shimizu T, Maeda M, Atomi Y, Watanabe J, Shoji $\mathrm{M}$, et al. Enhancing effect of bile and bile acid on stomach tumorigenesis induced by $\mathrm{N}$-methyl-N'-nitro-N-nitrosoguanidine in Wistar rats. J Natl Cancer Inst. 1984;73(4):853-61.

28. Kaminishi M, Shimizu N, Shiomoyama S, Yamaguchi H, Ogawa T, Sakai $S$, et al. Etiology of gastric remnant cancer with special reference to the effects of denervation of the gastric mucosa. Cancer. 1995;75(6 Suppl):1490-6.

29. Girelli CM, Cuvello P, Limido E, Rocca F. Duodenogastric reflux: an update. Am J Gastroenterol. 1996;91(4) 648-53.

Received in: 24/02/2016

Accepted for publication: 06/06/2016

Conflict of interest: none.

Source of funding: none.

\section{Mailing address:}

Humberto de Oliveira Serra

E-mail: hoserra@terra.com.br 